\title{
Absence of RNase III alters the pathway by which RNAl, the antisense inhibitor of ColE1 replication, decays
}

\author{
Uta Binnie $\nmid \nmid$ Kenny Wong, $\ddagger$ Sean McAteer and Millicent Masters
}

Institute of Cell and Molecular Biology, University of Edinburgh, The King's Buildings, Mayfield Road, Edinburgh EH9 3JR, UK
Author for correspondence: Millicent Masters. Tel: +44 131650 5355. Fax: +441316508650. e-mail: M.Masters@ed.ac.uk

RNAl is a short RNA, $108 \mathrm{nt}$ in length, which regulates the replication of the plasmid ColE1. RNAI turns over rapidly, enabling plasmid replication rate to respond quickly to changes in plasmid copy number. Because RNAI is produced in abundance, is easily extracted and turns over quickly, it has been used as a model for mRNA in studying RNA decay pathways. The enzymes polynucleotide phosphorylase, poly(A) polymerase and RNase $E$ have been demonstrated to have roles in both messenger and RNAI decay; it is reported here that these enzymes can work independently of one another to facilitate RNAI decay. The roles in RNAI decay of two further enzymes which facilitate mRNA decay, the exonuclease RNase II and the endonuclease RNase III, are also examined. RNase II does not appear to accelerate RNAI decay but it is found that, in the absence of RNase III, polyadenylated RNAI, unprocessed by RNase E, accumulates. It is also shown that RNase III can cut RNAI near nt 82 or 98 in vitro. An RNAI fragment corresponding to the longer of these can be found in extracts of an rnc ${ }^{+}$pcnB strain (which produces RNase III) but not of an rnc pcnB strain, suggesting that RNAI may be a substrate for RNase III in vivo. A possible pathway for the early steps in RNAl decay which incorporates this information is suggested.

Keywords: Escherichia coli, plasmid replication, RNA degradation, ribonuclease III, RNAI

\section{INTRODUCTION}

ColE1 regulates its copy number with a short RNA counter-transcript, RNAI. RNAI can hybridize to the complementary portion of a longer RNA, RNAII, and thus prevent its maturation into the primer used to initiate ColE1 replication. RNAI is synthesized constitutively from a strong promoter and its steadystate level is high relative to that of RNAII. However, it turns over rapidly. As a result, its concentration alters quickly in response to a change in plasmid copy number and replication is immediately inhibited or stimulated

\footnotetext{
†Present address: Inveresk Research International Ltd, Tranent, East Lothian, UK.

$\ddagger$ Present address: Asthma Genetics Group, Nuffield Department of Clinical Medicine, University of Oxford, John Radcliffe Hospital, Oxford OX3 9DU, UK.

Abbreviations: PAP I, poly(A) polymerase; PNPase, polynucleotide phosphorylase; RIF, rifampicin.
}

as appropriate (for reviews see Cesareni et al., 1991; Wagner \& Simons, 1994).

RNAI breakdown is rapid, and, like that of mRNAs (reviewed by Nierlich \& Murakawa, 1996; Kushner, 1996), is accomplished by a combination of endonucleases and exonucleases. For these reasons, it has been studied as a model for mRNA decay. Major roles in RNAI decay have been demonstrated for a number of enzymes. These enzymes are listed in Table 1. RNase E (Tomcsányi \& Apirion, 1985) is an essential enzyme with endonucleolytic activity important in messenger decay (Kuwano et al., 1977) and rRNA processing (Ghora \& Apirion, 1978). Lin-Chao \& Cohen (1991) showed that it has a major role in RNAI decay. Polynucleotide phosphorylase (PNPase) is one of the two exonucleases implicated in mRNA degradation (Donovan \& Kushner, 1986). Xu \& Cohen (1995) reported on its role in RNAI decay. Poly(A) polymerase (PAP I), discovered as a consequence of its role in plasmid copy number maintenance (Lopilato et al., 
Table 1. RNA decay enzymes

\begin{tabular}{|c|c|c|c|c|}
\hline Enzyme & Gene & Mutation & Enzyme activity & Substrate \\
\hline Ribonuclease E (RNase E) & rne & $\begin{array}{l}-1(\mathrm{Ts}) \\
-3071(\mathrm{Ts})\end{array}$ & Endonuclease (single strand) & mRNA, RNAI \\
\hline Polynucleotide phosphorylase (PNPase) & $p n p$ & -7 & $3^{\prime} \rightarrow 5^{\prime}$ Exonuclease & mRNA, RNAI \\
\hline $\operatorname{Poly}(\mathrm{A})$ polymerase (PAP I) & $p c n B$ & Deletion & 3' Adenylation & mRNA, RNAI \\
\hline Ribonuclease II (RNase II) & $r n b$ & Deletion & $3^{\prime} \rightarrow 5^{\prime}$ Exonuclease & mRNA \\
\hline Ribonuclease IIl (RNase III) & $r n c$ & Deletion & Endonuclease (double strand) & rRNA, mRNA, RNAI? \\
\hline
\end{tabular}

1986; March et al., 1989; Liu \& Parkinson, 1989; also reviewed by Sarkar, 1996, and Cohen, 1995), has since been implicated in mRNA decay (O'Hara et al., 1995; Hajnsdorf et al., 1995). Its central role in RNAI decay was demonstrated by both Cohen's group and our own (Xu et al., 1993; He et al., 1993).

Here we investigate whether the two remaining enzymes believed to have major roles in mRNA processing are implicated in RNAI decay. We present the first evidence that RNase III, an endonuclease involved in both the processing of rRNA (Dunn \& Studier, 1973) and the degradation or processing of a variety of messages (see Kushner, 1996, for references), also can affect RNAI degradation. On the other hand, RNase II, the second major exonuclease of mRNA degradation (Donovan \& Kushner, 1986), does not appear to have a role in RNAI decay.

RNase E and PNPase (but not PAP I) have been shown to be associated, with others, in a complex termed the 'degradosome' (Carpousis et al., 1994; Py et al., 1994; Miczak et al., 1996). We show here that these two enzymes can work separately in RNAI decay. Finally, we propose a pathway for the early stages of RNAI decay based on the half-lives of the primary and processed forms of RNAI in strains lacking one or more decay enzymes.

\section{METHODS}

Bacterial strains and plasmids. All experiments described were carried out using congenic strains constructed from Escherichia coli MM38 (Masters et al., 1993). Mutations in rne, rnc, pnp, $r n b$ and $p c n B$ were transferred into MM38, mainly by $\mathrm{P} 1$ transduction. The alleles used here and their sources are as follows: $p c n B \Delta-26$ is from MM38K26 (Masters et al., 1993); pnp-7 is from SK5726 (Yancey \& Kushner, 1990) and was originally isolated by Reiner $(1969) ; r n b \Delta-201\left(\right.$ Tet $\left.^{\mathrm{R}}\right)$ is from CMA201 (Piedade et al., 1995); rnb-500 (Ts), used in strain verification, is from SK6632 (Yancey \& Kushner, 1990) and was first described by Donovan \& Kushner (1986); rne-1 (Ts) is from HAK117 (Ono \& Kuwano, 1979); rne-3071 (Ts) is from N3431 (Apirion, 1978); and $r n c \Delta-38\left(\mathrm{Kan}^{\mathrm{R}}\right)$ is from SK7621 (Babitzke et al., 1993). To move interrupted genes $\left[r n c \Delta-38\left(\mathrm{Kan}^{\mathrm{R}}\right) ; r n b \Delta-201\left(\mathrm{Tet}^{\mathrm{R}}\right) ; p c n B \Delta-26\left(\mathrm{Kan}^{\mathrm{R}}\right)\right]$ the antibiotic-resistance marker was used for selection. pnp-7 inheritance was screened after selection of the linked $\arg G^{+}$ marker. A linked $\mathrm{Tn} 10\left(\mathrm{Tet}^{\mathrm{R}}\right)$ was transferred into the $r n e(\mathrm{Ts})$ $r n b$ (Ts) and $p c n B \Delta$ strains to facilitate the transfer of these alleles. In order to construct MM38 rne-3071 rnc $\Delta$ pcnBs it was necessary to introduce the $p c n B$ allele by conjugation. In cases where the inheritance of particular alleles in certain combinations could not be ascertained by phenotypic tests (i.e. resistance to a drug could be conferred in more than one way), backcrosses (P1 transduction) were used to verify constructions.

The following plasmids were used: pJF118EH (Furste et al., 1986), pBR325 (Bolivar, 1978), pCML108 (Lin-Chao et al., 1994), pLH1c (He et al., 1993) and pBAD-PCN. pBR325 and pJF118EH, closely similar pBR322-based replicons, were used interchangeably to produce RNAI. pCML108 is a pSC101based replicon from which RNAI, but no other ColE1-derived product, is expressed. In pLH1c, $p c n B$ is cloned downstream of ptac (which is leaky); however, it is also constitutively expressed from an upstream chromosomal promoter which is weaker than the native $p c n B$ promoter; the native promoter is not present in this construct (N. Binns, unpublished). pBAD$\mathrm{PCN}$ is a plasmid in which $p c n B$ expression is under the control of the arabinose-inducible pBAD promoter. Arabinose $(0.2$ or $0.4 \%)$ was added to induce the production or increase the concentration of PAP I during the course of an experiment. Expression from this promoter is almost completely inhibited by growth in the presence of $0 \cdot 2 \%$ glucose. pBAD-PCN was constructed by cloning 1460 bp PCR-amplified $p c n B$ DNA (from pJM513; March et al., 1989) into the EcoRI and HindIII sites of pBAD18 (Guzman et al., 1995). The primers used were (upstream) 5'-GCTAT GATTA GCCGG AATTC TTTTG TCCTG-3' and (downstream) 5'-CTGCC TATGG CAAGC TTCGC CACTG TCATG-3'.

RNAI half-life measurements. Cells were grown at $37^{\circ} \mathrm{C}$ in Lbroth, treated with rifampicin (RIF; $0.25 \mathrm{mg} \mathrm{ml}^{-1}$; Sigma) to stop further RNA synthesis and sampled at intervals. RNA was extracted, separated by size on polyacrylamide gels, transferred to a nylon membrane and Northern blots were made by hybridizing radioactively labelled oligonucleotide probes, specific for RNAI or for a tRNA control, to the membrane, all as described by He et al. (1993), except that RIF was added when the $\mathrm{OD}_{600}$ reached $0 \cdot 4$. Strains with temperature-sensitive mutations (rne-1 and rne-3071) were grown at $30^{\circ} \mathrm{C}$ to an $\mathrm{OD}_{600}$ of 0.3 and were then transferred to $44^{\circ} \mathrm{C}$ and grown for a further $60 \mathrm{~min}$ prior to the addition of RIF. tRNA is assumed to be stable and acts as a loading standard. The time-dependent change in RNAI/tRNA was used to calculate RNAI half-life graphically.

Preparation of RNA and Northern blot analysis. The protocols used for the extraction of RNA and Northern blot analysis were as described by He et al. (1993) with some changes. RNA was separated on $8 \%$ polyacrylamide $/ 7 \mathrm{M}$ urea denaturing gels and transferred to positively charged nylon membranes 
(Boehringer Mannheim) and fixed to the membrane by UV cross-linking, using a Stratagene UV Stratalinker at $1200 \mu \mathrm{J}$, $254 \mathrm{~nm}$. Oligonucleotide probes were end-labelled with ${ }^{32} \mathrm{P}$ using New England Biolabs polynucleotide kinase and following the manufacturer's protocol; hybridization was carried out according to Church \& Gilbert (1984). Hybridization signals were quantified using a Molecular Dynamics Phosphor Imager 400S (Molecular Dynamics) and Image-Quant version 3.22 software. Autoradiographs were made using Kodak XOmat film. Hybridizations using the UB6 oligonucleotide to detect $3^{\prime}$ polyadenylation were done at $40^{\circ} \mathrm{C}$; all others were done at $50{ }^{\circ} \mathrm{C}$. Filters requiring a second hybridization were stripped overnight in $100 \mathrm{ml} 50 \mathrm{mM}$ Tris/HCl $(\mathrm{pH} 8 \cdot 0)$, $0 \cdot 1 \mathrm{mM}$ EDTA, $0 \cdot 1 \%$ SDS at $65^{\circ} \mathrm{C}$.

Oligodeoxyribonucleotides. Oligonucleotides were purchased from Oswel DNA Service. The probe used to detect RNAI and for primer extension analysis was UB2 (5'-GATCA AGAGC TACCA ACTCT T-3'). The $\mathrm{tRNA}_{2}^{\text {ser }}$ probe, SS2 (He et al., 1993), was 5'-CCGGT AGAGT TGCCC CTACT CCGGT TTTAG-3'. Primers for the RT-PCR reaction were UB2 and UB1 (5'-ACAGT ATTTG GTATC TGCGC TCTGC-3') for the control reaction and UB6 (5'-TTTTT TTTTA ACAAA AAAAC CACC-3') and UB1 to establish the presence of adenylation.

Primer extension analysis. Primer extension analysis/reverse transcription was performed on total RNA extracted from cells harbouring the pBR325 plasmid. The method used was from Current Protocols in Molecular Biology (Triezenberg, 1992), and used 2-4 units AMV reverse transcriptase (Promega AMV; 5-10 units $\mu \mathrm{l}^{-1}$ ) and 10 pmol ${ }^{32} \mathrm{P}$-kinase end-labelled primer (T4 kinase; New England Biolabs), labelled as described by the manufacturer. Unincorporated nucleotide was removed using NAP-5 columns (Pharmacia). One-third of the reaction mix was loaded on an $8 \%$ polyacrylamide $/ 7 \mathrm{M}$ urea gel. Primer extension products were sized using a DNA sequencing ladder generated with a Pharmacia T7 Sequencing kit and the supplied M13 template.

RT-PCR. cDNA was generated from total RNA extracts using the UB6 or UB2 primer and AMV reverse transcriptase at $40{ }^{\circ} \mathrm{C}$ using the same methods as described for primer extension except that the primers were not labelled. Twentysix picomoles of additional primer (UB2 and UB1 for the control reaction or UB6 and UB1 to amplify polyadenylated sequences) was added to $10 \mu \mathrm{l}$ of the cDNA reaction product along with $200 \mu \mathrm{mol} \mathrm{dNTPs,} 1.5 \mathrm{mM} \mathrm{MgCl}_{2}$ and 2-5 units Taq polymerase (Promega Taq 5 units $\mu^{-1}$ ) in a final volume of $100 \mu \mathrm{l} \mathrm{Taq}$ buffer. A Hybaid Omnigene thermocycler and the following cycling conditions were used: 1 cycle at $94{ }^{\circ} \mathrm{C}$ for $3 \mathrm{~min}, 50^{\circ} \mathrm{C}$ for $30 \mathrm{~s}$ and elongation at $72{ }^{\circ} \mathrm{C}$ for $1 \mathrm{~min}$ followed by 30 cycles of $94^{\circ} \mathrm{C}$ for $1 \mathrm{~min}, 50^{\circ} \mathrm{C}$ for $30 \mathrm{~s}$ and elongation at $72^{\circ} \mathrm{C}$ for $1 \mathrm{~min}$. This was followed by a final elongation step at $72{ }^{\circ} \mathrm{C}$ for $10 \mathrm{~min}$. The PCR products were separated on a $1.25 \%$ agarose gel, in TBE buffer $(0.089 \mathrm{M}$ Tris/borate, 0.002 M EDTA). The amount of ethidiumstained product was measured directly using a Transilluminator and a UVP camera gel analysis system or a Southern blot was analysed using the Phosphor-Imager. The ratio of PCR products generated by the two primer pairs from a single RNA sample was taken as a measure of relative polyadenylation.

In vitro RNase III cleavage. In vitro cleavage of total RNA samples prepared as described above was performed using His-tagged RNase III and the method described by Li et al. (1993), with or without potassium glutamate. The purified
RNase III, the generous gift of A. Nicholson (Wayne State University, Detroit, MI, USA), had a concentration of $0 \cdot 14 \mu \mathrm{g} \mu \mathrm{l}^{-1}$. The final reaction volume of $20 \mu \mathrm{l}$ contained 5-10 $\mu \mathrm{g}$ RNA and $3 \mu \mathrm{l}$ RNase III. The reaction was incubated at $37^{\circ} \mathrm{C}$ for $0,10,20$ and $30 \mathrm{~min}$ and stopped with stop buffer (50\% deionized formamide, $20 \mathrm{mM}$ EDTA, $89 \mathrm{mM}$ Tris/ $\mathrm{HCl}, \mathrm{pH} 7 \cdot 5,89 \mathrm{mM}$ boric acid, $20 \%$ sucrose and $0 \cdot 1 \%$ each of bromophenol blue and xylene cyanol). Half of each reaction mix was loaded onto an $8 \%$ polyacrylamide $/ 7 \mathrm{M}$ urea gel and transferred to nylon as described above. Hybridization with an RNAI-specific probe was used to reveal the RNase III cleavage pattern of RNAI synthesized from pBR325 or pCML108.

\section{RESULTS}

\section{RNAl decay involves RNase E, PAP I and PNPase, but not RNase II}

RNAI is $108 \mathrm{nt}$ long and adopts a structure with three stem-loops and an unpaired $5^{\prime}$ region of 9 bases (see Fig. 1); it is unstable in vivo (Elble et al., 1983) and we find, in confirmation of earlier reports (Lin-Chao \& Bremer, 1986; Brenner \& Tomizawa, 1991; Lin-Chao \& Cohen, 1991; He et al., 1993), that it decays rapidly with a halflife of about $2 \mathrm{~min}$ at $37^{\circ} \mathrm{C}$ (Table 2).

The absence of RNase E, PAP I and PNPase has previously, as cited above, been shown to slow RNAI decay and we confirm this here (Table 2 lists the halflives of RNAI in RNA-decay mutants). Fig. 2( $a$, b and d) are Northern blots which show the decay of RNAI in particular mutant strains. In the absence of PAP I (and RNAII) $\mathrm{RNAI}_{103}$, the primary product of RNase E processing, and some shorter processed forms of lengths $\sim 93$ (Fig. 2a, lane 1; this band is obscured by tRNA in lanes $2-7), \sim 83, \sim 73 / 71$ and $\sim 65$ can be observed. $\mathrm{RNAI}_{103}$, the principal processed RNAI product and barely detectable in $p c n B^{+}$hosts, has a half-life of 25 min, as previously observed. The $65 \mathrm{nt}$ band appears as the $83 \mathrm{nt}$ band disappears (lanes 4-7), suggesting that it may originate from it. The stable doublet labelled $73 / 71$ is probably identical to the $70 / 67$ pair identified as minor products of RNase E action (Kaberdin et al., 1996). We calculate that, at the time of RIF addition, these shorter forms, together, have about one-third the abundance of RNAI ${ }_{103}$. The RNAI analysed here was transcribed from pCML108, which does not have the RNAII coding sequence. We find that, in the absence of RNAII and PcnB, a condition not previously analysed, these decay bands are particularly easy to observe, suggesting that RNAI:RNAII hybrids are probably degraded more efficiently than is folded RNAI.

In a PNPase-deficient strain a diffuse band of material, varying upwards in length from $103 \mathrm{nt}$, is apparent (Fig. $2 \mathrm{~b}$, lane 6). Reverse transcription analysis shows that most of this material has the RNase E processed 5' end (Fig. 2c; and $\mathrm{Xu} \&$ Cohen, 1995) and thus must be lengthened at the $3^{\prime}$ end. Its absence in a $p c n B$ p $n p 7$ strain (Fig. 2b, lanes 1-5) suggests that it represents adenylated material. These confirmatory results are included here for comparative purposes. 


\section{RNA I}

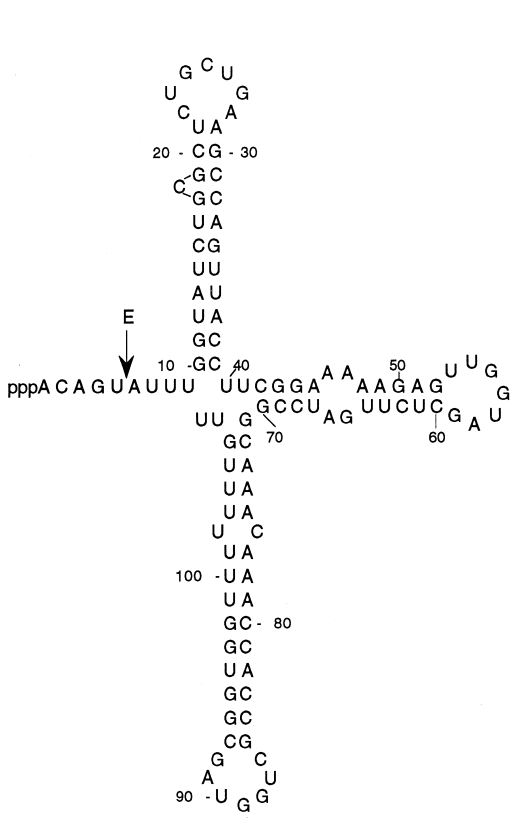

RNA I (A)

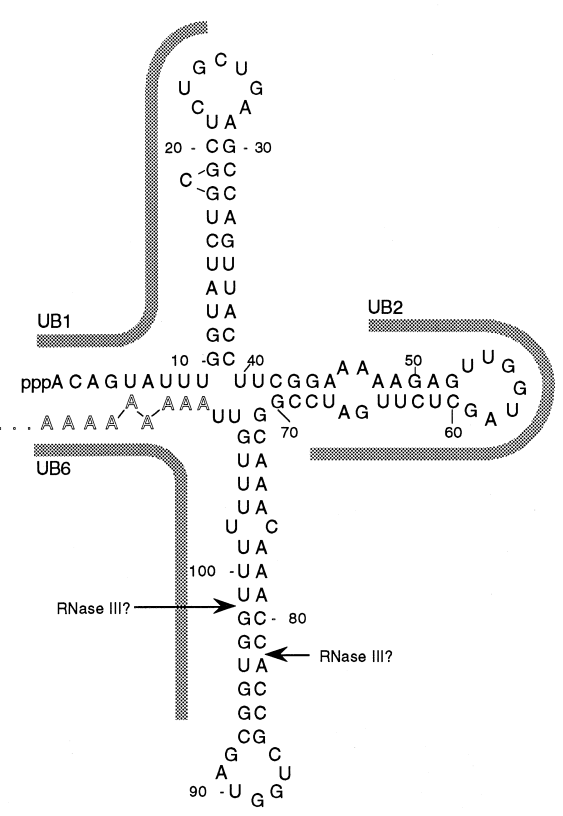

Fig. 1. Structure of RNAl (redrawn from various published structures, i.e. Xu et al., 1993) and a notional adenylated form. E, RNase E cutting site; RNase III?, possible RNase III cutting sites. Composition of primers/probes used in this study is indicated.

Table 2. Half-lives of RNAl forms in some RNA decay mutants

\begin{tabular}{|c|c|c|c|c|c|c|c|}
\hline \multicolumn{5}{|c|}{ Genotype } & \multicolumn{3}{|c|}{ RNAI half-life* } \\
\hline$p c n B$ & rne & $r n c$ & $p n p$ & $r n b$ & 108 & 103 & 108 ext \\
\hline+ & + & + & + & + & $1 \cdot 8 \pm 0 \cdot 3$ & $1 \cdot 3$ & \\
\hline+ & ts & + & + & + & $7 \cdot 3 \pm 1 \cdot 6$ & - & \\
\hline$\Delta$ & + & + & + & + & $1-2$ & 25,30 & \\
\hline+ & + & + & 7 & + & $6,10,11 \dagger$ & & \\
\hline+ & + & + & + & $\Delta$ & $1 \cdot 5,3$ & - & \\
\hline+ & + & $\Delta$ & + & + & $7 \cdot 5 \pm 1 \cdot 5 \neq$ & $3 \pm 0 \cdot 6$ & $76 \pm 24$ \\
\hline$\Delta$ & + & + & + & $\Delta$ & - & 27,25 & \\
\hline+ & ts & $\Delta$ & + & + & $15 \neq$ & - & 70 \\
\hline$\Delta$ & + & $\Delta$ & + & + & - & 28 & \\
\hline$+++\mathbb{S}$ & + & + & + & + & $1 \cdot 9,0 \cdot 4$ & - & 0.5 \\
\hline$\Delta$ & ts & + & + & + & $8,16,20$ & Stable & \\
\hline$\Delta$ & ts & $\Delta$ & + & + & 16 & Stable & \\
\hline
\end{tabular}

*Half-lives, in minutes, were measured for all distinguishable RNAI forms either at $37^{\circ} \mathrm{C}$, or, for rne(Ts) strains, at $44{ }^{\circ} \mathrm{C}$. Each measurement represents an independent half-life determination. In cases where three or fewer independent measurements were available, all are listed. In the remaining cases means and standard deviations are shown. Results for multiple mutants are listed below the empty row; all mutations were transferred to the MM38 background (see Methods).

† We were unable to distinguish $\mathrm{RNAI}_{108}$ from adenylated $\mathrm{RNAI}_{103}$ in $p n p$ strains; this is a composite half-life.

$\ddagger$ These are initial decay rates and are composite values for $\mathrm{RNAI}_{108}$ and any extended material present.

$\mathbb{S}$ These experiments were done with MM38 pLH1c, in which $p c n B$ is expressed at high levels. Half-lives are consistently shorter than in strains with a single $p c n B$ copy measured at the same time.

To test whether RNase II has any significant role in RNAI decay we measured the half-lives of $\mathrm{RNAI}_{108}$ in MM38 (Fig. 2d) and $\mathrm{RNAI}_{103}$ in MM38 pcnB rnb (Northern blot not shown). RNAI ${ }_{108}$ decays at about the same rate in the presence or absence of RNase II (Fig. $2 \mathrm{~d}$; and Table 2, rows 1 and 5); the rate of RNAI ${ }_{103}$ decay is also unchanged in the absence of RNase II (Table 2, rows 3 and 7). 
(a) $p c n B$

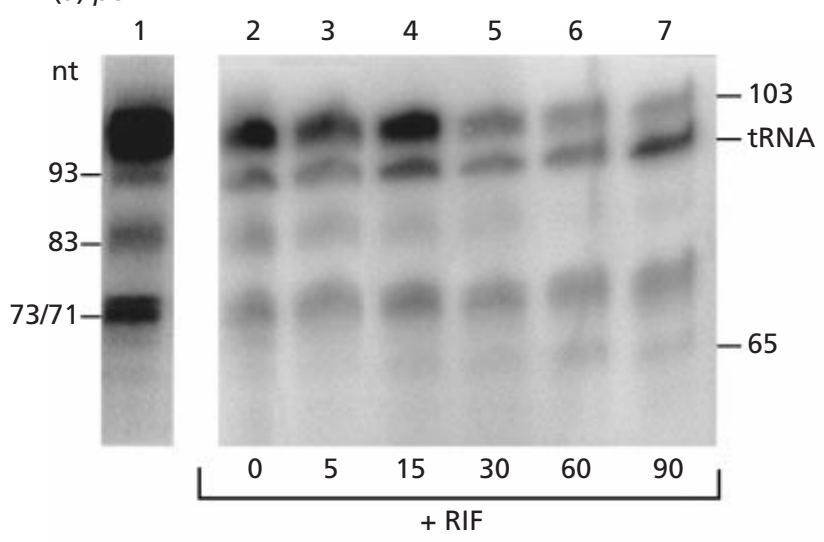

(b) $p n p 7$

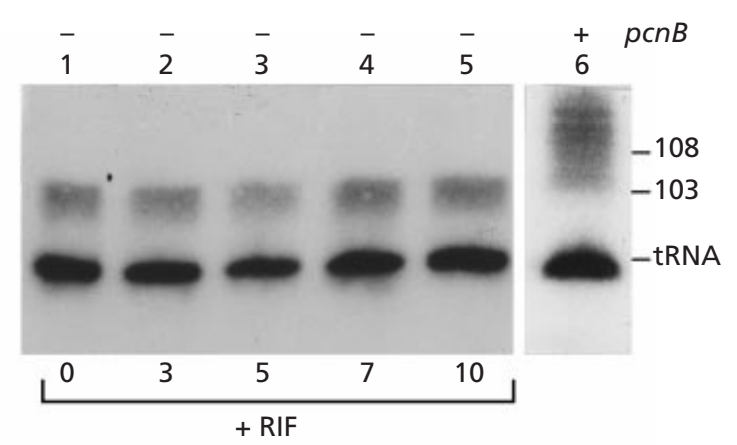

(c)

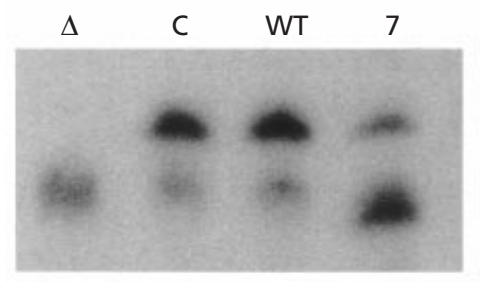

C

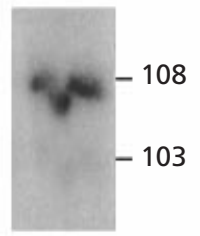

60 (d) $r n b$

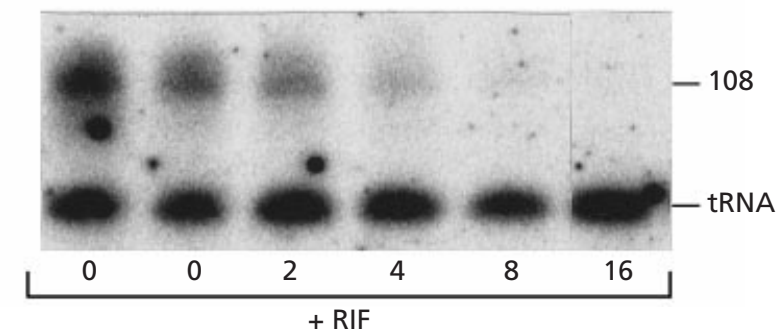

Fig. 2. RNAl decay in pcnB and RNA exonuclease mutants. All panels show Northern blots carried out as described in Methods. ( $a, b, d)$ RNAl decay after RIF addition to LB cultures of the indicated mutants. Times are in minutes relative to the time of RIF addition. Probes (see Methods) are, for RNAI, UB2, and for tRNA, SS2. tRNA 2 ser (88 nt) was used as a loading standard in time-courses. (a) MM38 $\triangle p c n B$ (pCML108); lane 1 shows a RIF-untreated sample not hybridized to the tRNA probe, in order not to obscure the band at $93 \mathrm{nt}$. (b) RNAl in pnp-7 pcnB/pcnB ${ }^{+}$(pBR325) strains. Lanes 1-5, RNAI decay in MM38 pnp-7 $\triangle p c n B$; lane 6, RNA extracted from MM38 pnp-7. (c) Reverse transcription analysis of 5' RNAl ends. RNA was extracted from growing cells, except for the 60 min rnc sample from which RNA was extracted 60 min after RIF addition. A sequencing ladder (not shown) was used to verify that the sizes of RT products were as predicted. $\Delta, p c n B ; C$, rnc; wt, MM38; 7, pnp-7. All strains contained pBR325. (d) RNAl decay in MM38 $\Delta r n b$ (pJF118EH).

\section{A second, RNase-E-independent, path of RNAI decay involves RNase III}

Fig. 3 shows Northern blot analyses of RNAI decay in rne and rnc strains. Fig. 3(b) (top curve) shows that RNAI $_{108}$ decays in MM38 rne-3071 with a half-life of $\sim 8 \mathrm{~min}$ when the enzyme is inactivated at $44^{\circ} \mathrm{C}$, fourfold slower than in non-mutant cells (see also LinChao \& Cohen, 1991). Although some $\mathrm{RNAI}_{108}$ remains even 60 min after RIF addition (Fig. 3a), it is clear that RNAI can be degraded independently of RNase E. To test whether this might require RNase III, the second principal endonuclease with a known role in mRNA processing, we constructed an rnc rne-3071 double mutant. Fig. 3(c) shows that, in MM38 rnc rne-3071, significant amounts of RNAI remain at $60 \mathrm{~min}$ after RIF addition, but principally as a novel form of increased length $\left(\mathrm{RNAI}_{\text {ex }}\right)$, rather than as $\mathrm{RNAI}_{108}$. The half-life of total RNAI is increased to $33 \mathrm{~min}$ in the double mutant. In an $r n e^{+} r n c$ strain $\mathrm{RNAI}_{\text {ex }}$ also accumulates (Fig. 3d), suggesting that it is not a substrate for RNase
E. We conclude that RNase III is required either to remove, or to prevent the formation of, $\mathrm{RNAI}_{\mathrm{ex}}$.

Reverse transcription analysis of RNA extracted from an $r n c$ strain after $60 \mathrm{~min}$ with RIF showed that the remaining RNAI (virtually all $\mathrm{RNAI}_{\mathrm{ex}}$; Fig. 3d) has a native $5^{\prime}$ end (Fig. 2c, rt.). Therefore RNAI $\mathrm{Rx}_{\mathrm{ex}}$ is made by extending $\mathrm{RNAI}_{108}$ at the $3^{\prime}$ end of the molecule. Fig. 3 (d) also shows that $\mathrm{RNAI}_{103}$ (absent from rne strains) decays in $r n c$ strains at a moderately reduced but still rapid rate (Table 2 ; Fig. $3 \mathrm{~b}$, lowest curve). Therefore RNase III is not important for the adenylation-dependent decay of this RNase E processed form. Note that the mean length of $\mathrm{RNAI}_{\mathrm{ex}}$ increases after RIF treatment, reaching a maximum of $\sim 116$ nt at about 16 min. After longer times the mean length again decreases.

Closer examination of the kinetics of RNAI decay in $r n c$ strains shows that the fates of $\mathrm{RNAI}_{108}$ and $\mathrm{RNAI}_{\mathrm{ex}}$ are very different. This is shown in Fig. 3(b) in which the decay of $\mathrm{RNAI}_{108}+\mathrm{RNAI}_{\mathrm{ex}}$ (middle curve) is plotted. 
(a) rne
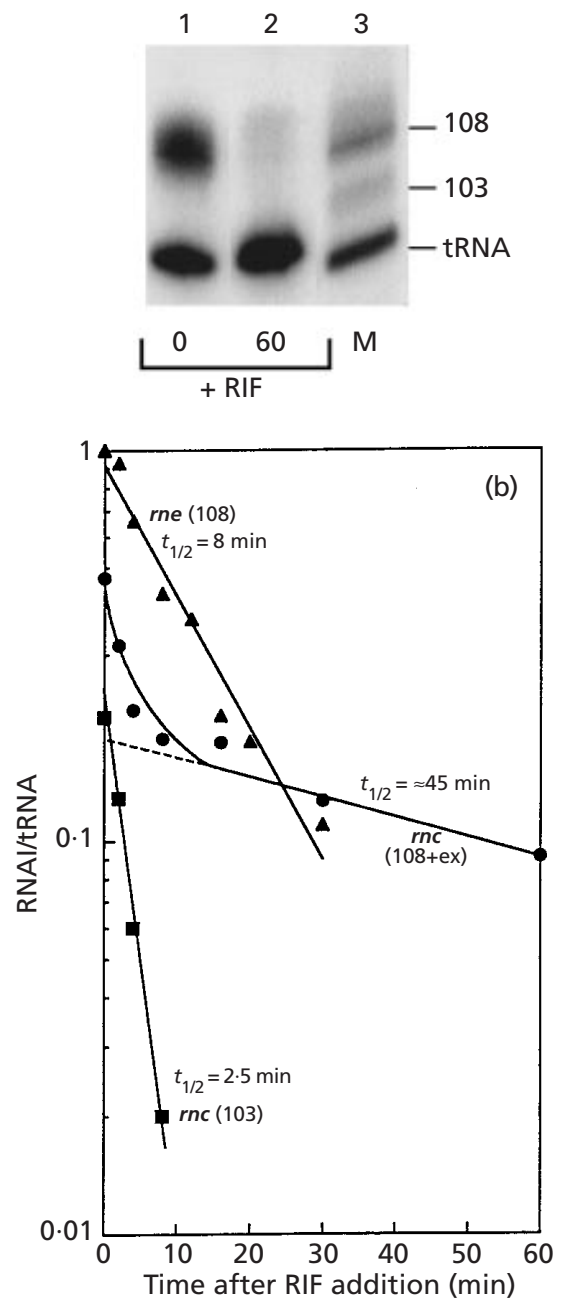

(c) rnc rne

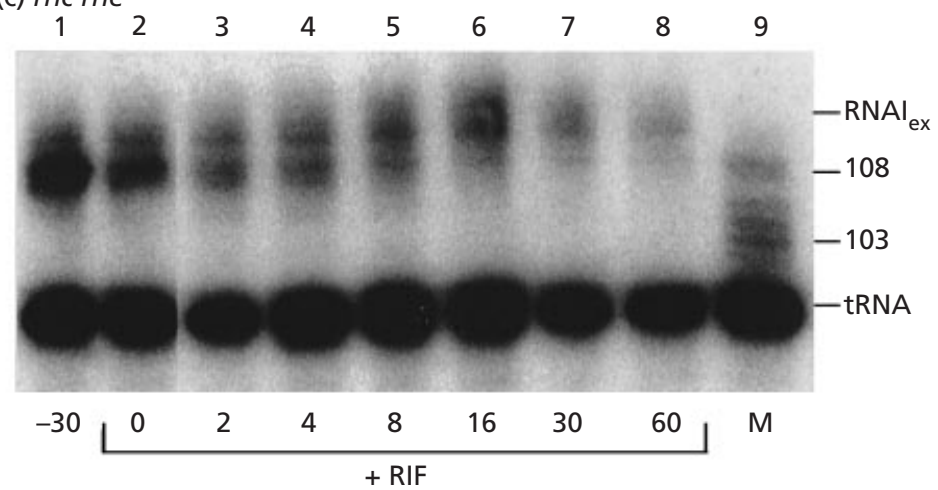

(d) $r n c$

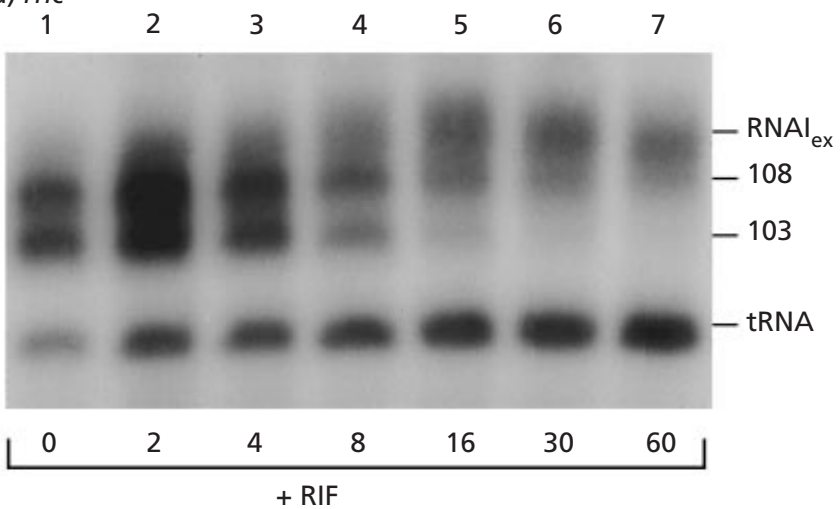

Fig. 3. Decay of RNAI in RNA endonuclease mutants. (a, c, d) Northern blots of RNA extracts of the indicated mutants sampled at the noted times relative to RIF addition. Methods and probes were as for Fig. 1 ; all strains contained pBR325. RNAl markers (labelled M), where included, were prepared by mixing extracts of plasmid-containing $p c n B$ and $p c n B^{+}$ strains to ensure that both $\mathrm{RNAl}_{103}$ (the predominant form in $p c n B$ strains) and $\mathrm{RNAl}_{108}$ (the predominant form in $p c n B^{+}$ strains) would be visible. rne strains were grown at $30{ }^{\circ} \mathrm{C}$ and transferred to $44{ }^{\circ} \mathrm{C} 1 \mathrm{~h}$ before RIF addition. (a) MM38 rne3071; 0 and 60 min samples are shown in this panel, but values for all points up to 30 min are plotted in (b). (b) Decay curves for RNAI from rne and rnc strains. The upper line (rne) shows RNAI ${ }_{108}$ decay in MM38 rne-3071 ( $\boldsymbol{\Delta}$ ), the middle line $(r n c)$ shows decay of RNAI + RNAI ${ }_{\text {ex }}$ in MM38 $\Delta r n c(\mathbf{O})$, and the bottom line $(r n c)$ shows the decay of RNAI ${ }_{103}$ ( $\left.\boldsymbol{\square}\right)$. Calculated RNAI half-lives $\left(t_{1 / 2}\right)$ are shown. (c) RNAI decay in MM38 rne-3071 $\Delta r n c$. (d) RNAI decay in MM38 $\Delta r n c$ grown at $37^{\circ} \mathrm{C}$.

The complex shape of this curve results from the initial (most likely RNase E mediated) rapid decay of $\mathrm{RNAI}_{108}$ combined with the conversion of a substantial fraction of $\mathrm{RNAI}_{108}$ into the much more stable RNAI $\mathrm{Rex} \cdot \mathrm{RNAI}_{\mathrm{ex}}$ has an approximate half-life of $45 \mathrm{~min}$ in this experiment.

\section{$\mathrm{RNAI}_{\text {ex }}$ is likely to be PAP I adenylated}

The longer form of RNAI, $\mathrm{RNAI}_{\mathrm{ex}}$, which appears in $r n c$ strains is likely to be adenylated $\mathrm{RNAI}_{108}$. Observations which suggest this are shown in the Northern blots in Fig. 4(a-c). Firstly, extended $\mathrm{RNAI}_{108}$ is not observed in an $r n c p c n B$ strain (Fig. 4a), indicating that PAP I activity is required for it to be made. Conversely, if PAP I is overexpressed in an $r n c$ strain an increasing proportion of extended RNAI is observed as PAP I concentration increases (Fig. 4b). In the experiment shown, the production of PAP I was induced by addition of arabinose to MM38 rnc (pBAD-PCN), a strain in which PAP I production is under the control of the $\operatorname{araBAD}$ promoter. Overproduction of PAP I also promotes the production of extended RNAI in $\mathrm{rnc}^{+}$ strains; this material is not long-lived (Fig. 4c). 
(a) $r n c p c n B$

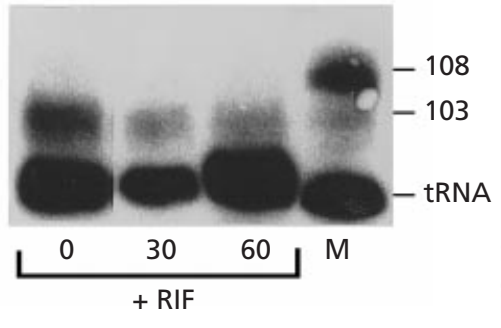

(d) (b) $r n c(p B A D-P C N)$

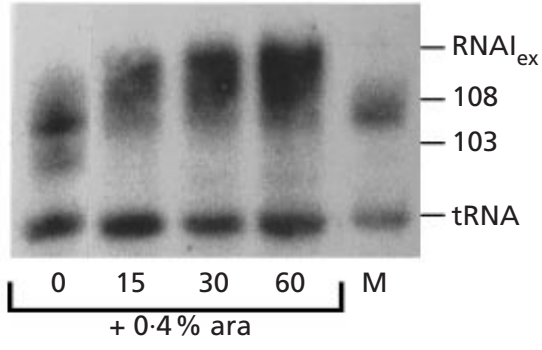

(c) $p c n B(p L H 1 c)$

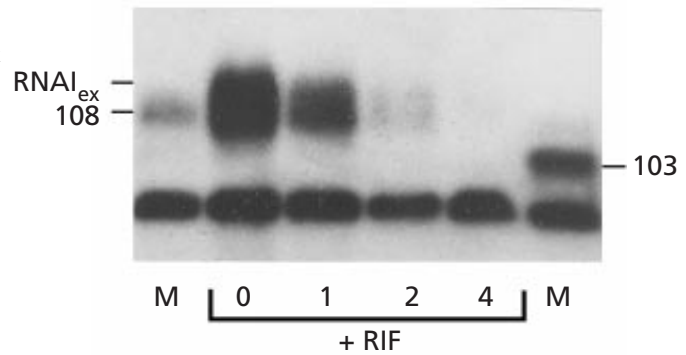

(e)

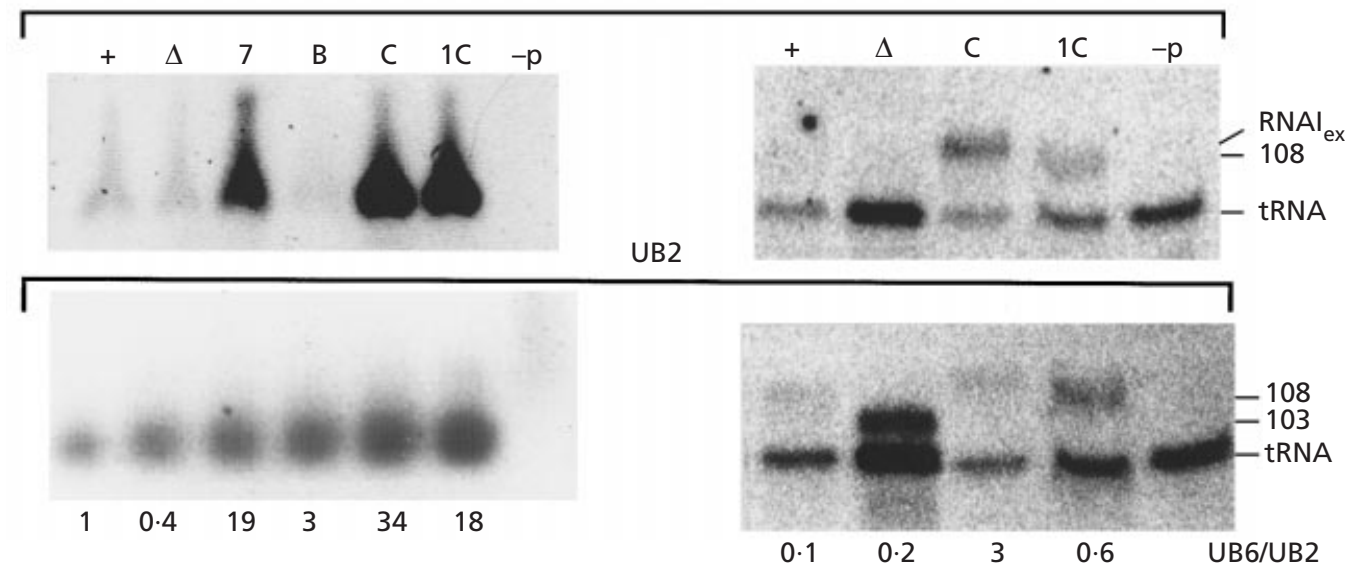

Fig. 4. Evidence that $\mathrm{RNAl}_{e x}$ is adenylated. $(\mathrm{a}, \mathrm{b}, \mathrm{c})$ Northern blots, probed as for Fig. 1. The Northern blots in (e) were successively probed with UB2, the standard RNAI probe, and UB6, a probe containing a $5^{\prime}$ series of T residues and used to detect polyadenylation. $M$ indicates RNAI markers: [RNAl from $p c n B^{+}$in (b), $p c n B$ and $p c n B^{+}$in separate lanes in (c) and mixed in (a)]. (a) Samples from an RNAl decay series for MM38 $\Delta p c n \Delta r n c$ (pJF118EH). In (b) PAP I production was induced in MM38 $\Delta r n c$ (pBAD-PCN) with $0.4 \%$ arabinose added at $t=0$. (c) Decay of RNAl forms found in MM38 (pLH1c). This strain produces PcnB at high levels from ptac without the addition of IPTG, which was not added here. (d) RT-PCR products from pBR325-containing mutants, as described in Methods. The UB6 primer was used to reverse-transcribe adenylated RNAI, and the UB2 primer to reverse-transcribe total RNAI. The CDNA produced was PCR-amplified after adding the primer UB1 to both reactions. DNA was separated on agarose gels and stained with EtBr; photographs are shown. Ratios are of UB6 to UB2 primed product, normalized to the MM38 ratio, and were obtained by scanning photographs of the stained gels. +, MM38; $\Delta$, MM38 $\Delta$ pcnB; 7, MM38 pnp-7; B, MM38 $\Delta r n b ; C$, MM38 $\Delta r n c$ (all with pBR325); 1C, MM38 (pLH1c); - p, MM38 (plasmid-free). (e) Northern blot analysis of RNAl adenylation. RNA extracts from exponential cultures of the indicated strains were separated on polyacrylamide gels and transferred to a filter which was hybridized with the first probe set (UB6 + SS2), stripped and rehybridized with the second set (UB2 + SS2). Ratio is of (UB6/tRNA) to (UB2/tRNA).

To demonstrate that $\mathrm{RNAI}_{\mathrm{ex}}$ is adenylated, RT-PCR amplification was carried out using UB6, a primer which includes nine $5^{\prime} \mathrm{dT}$ residues, for selective reverse transcription of adenylated RNAI. The primer UB2, which is not dT-rich, was used in a parallel reaction as a control. Fig. 4(d) shows an EtBr-stained agarose gel of the PCR-amplified products obtained in this way. Significant amounts of UB6 primed amplified product were obtained only with RNA from control strains carrying the pnp-7 mutation, or overexpressing PAP I from pLH1c, in which adenylation is known to be enhanced, thus validating the technique. The amount of RT-PCR product obtained in this way from the $r n c$ strain was as great as that produced from the hyperadenylating control strains.
Direct Northern blotting of RNAs from different mutant strains was also done using ${ }^{32}$ P-labelled UB6 and UB2 oligonucleotides as probes. Fig. 4(e) shows that the UB6 probe, designed to detect adenylated RNAI, hybridized preferentially to the RNAI extracted from the rnc mutant or from the PAP I overproducer. The control probe hybridized to all forms of RNAI in each strain. This is the result expected if UB6 is specific for polyadenylated RNAI and if, amongst the strains tested here, RNAI is only extensively polyadenylated in the RNase-III-deficient and PAP-I-overproducing strains. Taking all of the above evidence together, we conclude that $\mathrm{RNAI}_{\mathrm{ex}}$ is likely to be a 3' adenylated form of $\mathrm{RNAI}_{108}$ (to be referred to as $\mathrm{RNAI}_{108} \mathrm{~A}_{\mathrm{n}}$ ) which is produced by PAP I adenylation of RNAI 108 . 
(a)

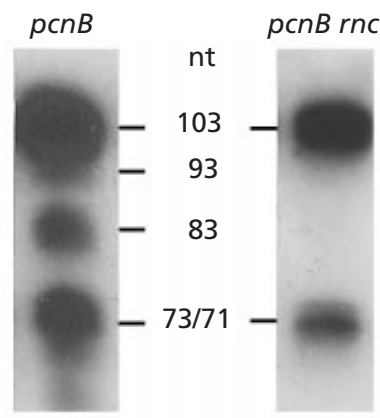

(b) $r n e-1 p c n B$

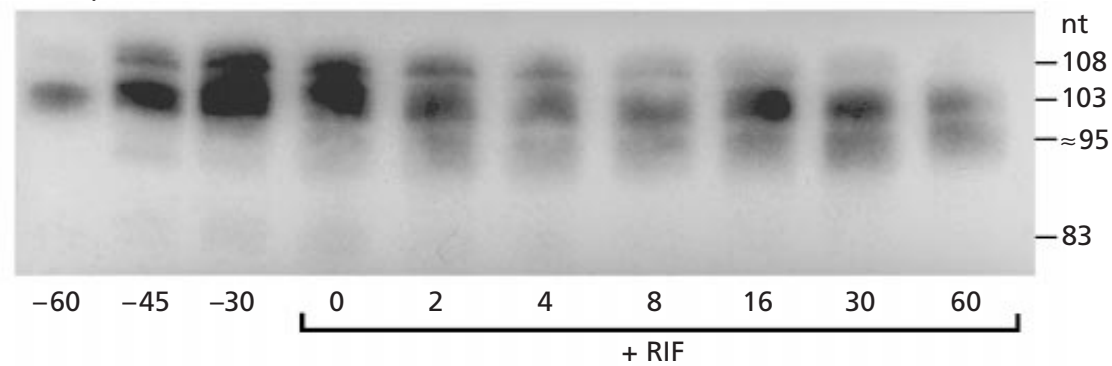

(c)
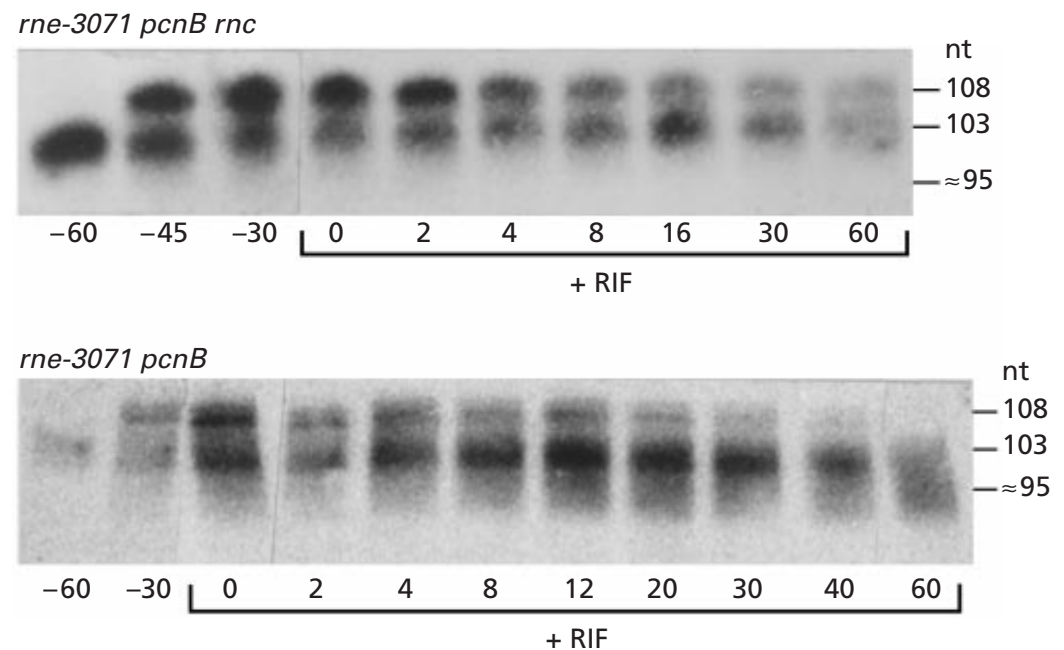

Fig. 5. Evidence for possible RNase III cutting in vivo. All panels show Northern blots. (a) RNAI from MM38 $\triangle p c n B$ (pCML108) compared with that from MM38 $\triangle p c n B \Delta r n c$ (pCML108). Autoradiograms shown here were highly exposed to detect possible faint bands. (b) Decay of RNAI in MM38 rne-1 $\Delta p c n B$ (pJF118EH). Cultures were grown at $30^{\circ} \mathrm{C}$ and transferred to $44^{\circ} \mathrm{C} 1 \mathrm{~h}$ before the addition of RIF. (c) MM38 rne-3071 $\Delta p c n B \Delta r n c$ (pBR325) (upper) and $r n c^{+}$(lower), prepared as in (b).

\section{Is RNAI a substrate for RNase III cutting?}

The experiments described above demonstrate that a stable, adenylated form of $\mathrm{RNAI}_{108}$ accumulates in the absence of RNase III. This could mean that either RNase III itself cuts RNAI ${ }_{108} A_{n}$, or RNase III works indirectly by, for instance, facilitating the production of the actual degrading enzyme. To distinguish between these possibilities we attempted to identify possible products of RNase III cleavage in vivo and in vitro. Our results, although not conclusive, show that RNase III can cut RNAI, but cannot define an in vivo substrate.

\section{Possible products of RNase III cutting in vivo}

Since the degradation products of adenylated RNAI disappear too rapidly to be observed on Northern blots we examined the more stable processed forms of unadenylated RNAI extracted from $p c n B$ strains to see whether their presence is RNase III dependent. Fig. 5(a) shows that two bands of $\sim 93 \mathrm{nt}$ and $\sim 83 \mathrm{nt}$ in size, visible in $p c n B$ extracts, are absent from $p c n B r n c$ extracts, and are thus candidate products of RNase III cutting. We also examined $p c n B$ rne extracts since they lack both major enzymes thought to initiate RNAI decay. The Northern blot in Fig. 5(b) shows extracts of MM38 rne-1 $\triangle p c n B$ sampled after RIF inhibition of RNA synthesis. As RNAI decays, a $\approx 95$ nt degradation product of RNAI appears. The band is broad and could contain a mixture of the products of $\mathrm{RNAI}_{103}$ and $\mathrm{RNAI}_{108}$ cut at or near nt 98. The kinetics of disappearance of $\mathrm{RNAI}_{103}$ and $\mathrm{RNAI}_{108}$ and of the appearance of the $\approx 95 \mathrm{nt}$ form (data not shown) is consistent with this interpretation.

Curiously, the combination of $r n e-1$ and $\Delta r n c$ was not tolerated in either MM38 or in MG1655, preventing us from testing whether the formation of the $95 \mathrm{nt}$ form is dependent on RNase III in an rne-1 mutant. However, MM38 rne-3071 $\Delta r n c \Delta p c n B$ and MM38 rne-3071 $\Delta p c n B$ could be constructed and RNAI decay was followed in this congenic pair of strains. No diffuse band at $\approx 95 \mathrm{nt}$ is seen when RNase III is absent (Fig. 5c, upper) but RNAI of this length is observed when RNase III is available (Fig. 5c, lower). 
(a)

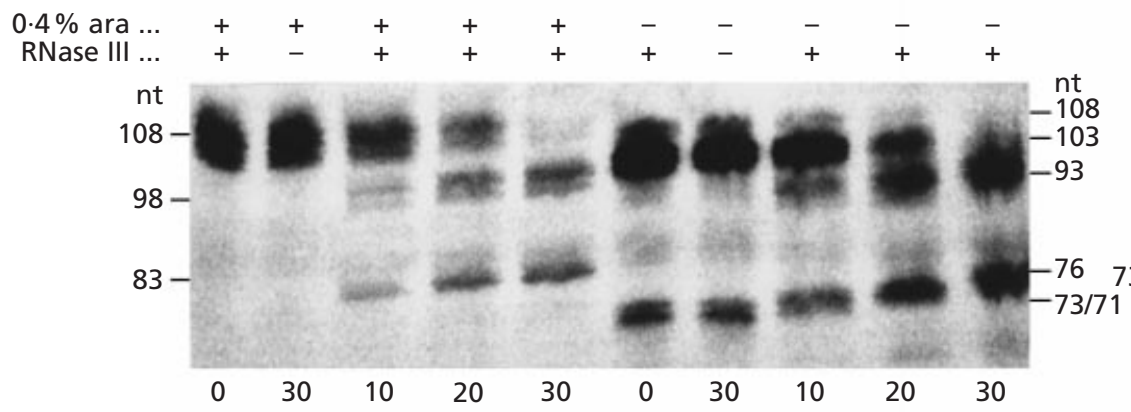

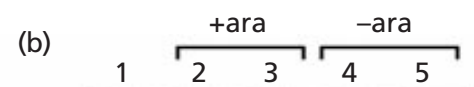

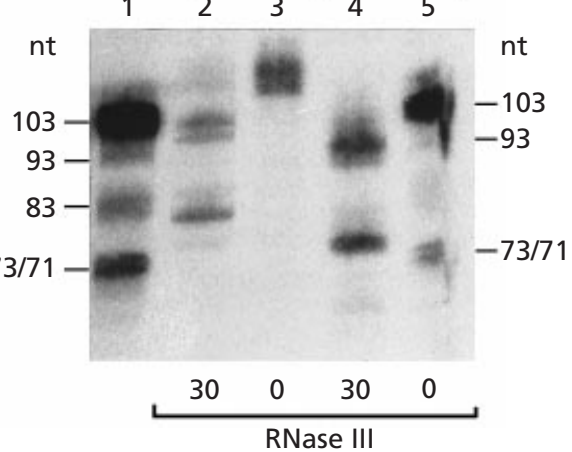

Fig. 6. (a) In vitro cutting of RNAl extracted from MM38 $\triangle p c n B$ (pBAD-PCN) grown with $0.4 \%$ arabinose (indicated on top line) or $0.2 \%$ glucose. Purified, deproteinized RNA was cut with RNase III at $37^{\circ} \mathrm{C}$ under low-salt conditions, as described in Methods, for the number of minutes indicated. RNAI and its fragments were detected by hybridization with UB2 and sized with reference to a sequencing ladder. (b) Northern blots to compare sizes of RNAI ${ }_{103}$ decay products extracted from cells with those produced by RNase III cleavage in vitro. Run on a single gel are: extract of MM38 $\triangle p c n B$ (pCML108) (lane 1); MM38 $\triangle p c n B$ (pBAD-PCN) RNase III cleaved samples (lanes 2-5) (also shown on the gel in Fig. 6a) grown + ara (lanes 2-3) or - ara (+glu) (lanes 4-5). Length of incubation (min) with RNase III is shown at the bottom.

\section{RNase III can cut RNAl in vitro}

If RNase III were able to cut RNAI in vitro, in the absence of any other enzymes of RNA metabolism, to yield products of the same $\operatorname{size}(\mathrm{s})$ as the RNase-IIIdependent bands identified in vivo this would support the hypothesis that RNase III can cut RNAI in the cell. Protein-free extracts of RNA were prepared from MM38 pcnB (pBAD-PCN) grown with either arabinose (to induce PAP I production) or glucose (to repress production) and digested with purified RNase III using a standard protocol (Li et al., 1993). No cutting of RNAI was observed (data not shown). However, when the salt (potassium glutamate), generally considered to be required for specificity of cutting, was omitted from the reaction mixture, cutting was observed. Fig. 6(a) shows a Northern blot of samples taken during RNase III treatment. All forms of RNAI present are fully and specifically processed to yield two major products each. Since the $103 \mathrm{nt}$ and $108 \mathrm{nt}$ forms are cut to yield products differing in size by 5 bases, the sites of cutting must be near the $3^{\prime}$ rather than near the $5^{\prime}$ end of RNAI, with the longer product resulting from a cut near nt 98 and the shorter from a cut near nt 82 (indicated in Fig. 1 ). When RNAI is folded these bases are close together in a double-stranded region flanking two GC pairs which are in turn flanked by AU pairs. This putative cutting site resembles that identified in $\mathrm{rncO}$ (Matsunaga et al., 1996; Bardwell et al., 1989). The material in the $73 / 71$ doublet band prominent in the absence of PAP I is also rapidly processed by $\mathrm{RNase}$ III.

To see whether either of the RNase III products observed in vitro correspond in size to RNase-III-dependent in vivo products, the extract used in Fig. 5(a) was run alongside of the in vitro cut material. This is shown in Fig. 6(b). A product $93 \mathrm{nt}$ in length is found in both extracts and thus could be an in vivo product of RNase III digestion.

\section{RNase-III-dependent cutting of RNAI does not require RNAII}

RNase III cuts both double-stranded RNA and folded single-stranded RNA. Since RNAI forms a hybrid with RNAII it is possible that this hybrid, rather than RNAI, is the primary substrate for RNase III. Indeed, Tomizawa \& Itoh (1981) reported that this was the case in vitro. As there is less than $10 \%$ as much RNAII as RNAI in broth-grown cells, most RNAI will be unhybridized, making it unlikely that only RNAI : RNAII hybrid is being cut. However, to confirm that RNAII is not required for RNase III cutting of RNAI, we repeated several of the experiments described above using pCML108 (Lin-Chao et al., 1994), a pSC101 derivative which produces RNAI but not RNAII, to supply RNAI. RNAI extracted from pCML108 strains can also be cut by RNase III in vitro to yield fragments of the sizes described above. Extended RNAI also accumulates in an $r n c$ strain with this plasmid (data not shown), showing that hybridization with RNAII is not required to produce material which requires $\mathrm{RNase}$ III for its removal.

\section{DISCUSSION}

\section{Is the in vivo role of RNase III in RNAI breakdown direct or indirect?}

We have shown that, in the absence of RNase III, an extended, adenylated, stable form of RNAI, RNAI ${ }_{108} A_{n}$, is made. We can think of three possible origins for RNAI $_{108} A_{n}$. (1) Lack of RNase III could itself stimulate the formation of $\mathrm{RNAI}_{108} \mathrm{~A}_{\mathrm{n}}$, a form not ordinarily made at all, and for which there is no mechanism of decay. We do not think that this is so because when adenylation of RNAI is artificially increased by overexpressing $p c n B$ in $r n c^{+}$strains, $\mathrm{RNAI}_{108} \mathrm{~A}_{\mathrm{n}}$ is formed but does not have an increased half-life (Fig. 4c). (2) 


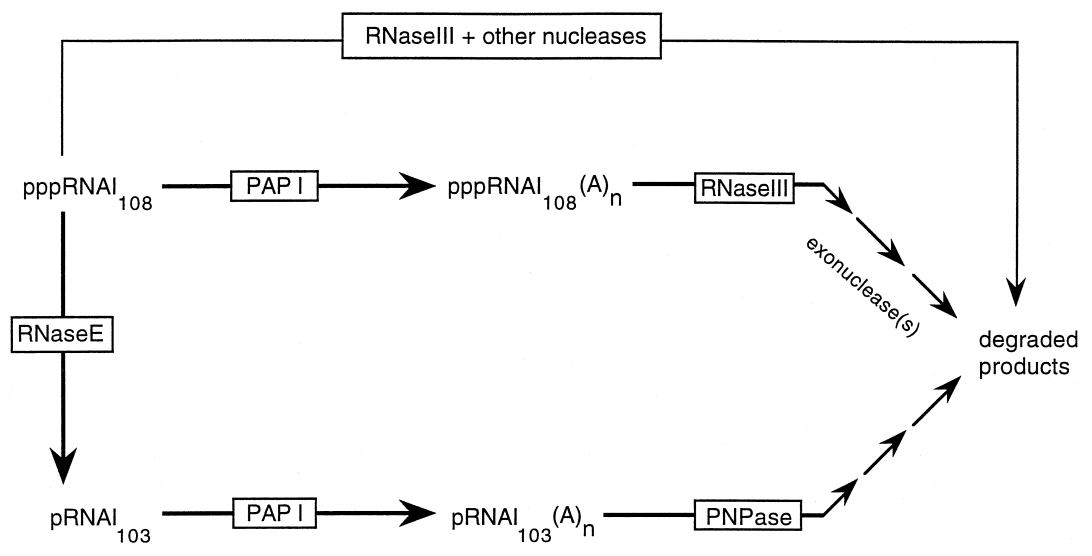

Fig. 7. Possible pathway for RNAI decay in the cell.

Lack of RNase III promotes the formation of an inhibitor that interferes with the degradation of $\mathrm{RNAI}_{108} \mathrm{~A}_{\mathrm{n}}$, or prevents the formation of an unidentified nuclease that normally would degrade it. We cannot exclude these possibilities (which would themselves be interesting), but it is worth noting that the level of a candidate nuclease, PNPase, is increased rather than decreased in $r n c$ mutants (Portier et al., 1987). (3) RNase III has a direct role in RNAI degradation, that of initiating the decay of $\mathrm{RNAI}_{108} \mathrm{~A}_{\mathrm{n}}$.

Distinguishing between (2) and (3) depends on determining whether RNAI (or RNAI ${ }_{108} \mathrm{~A}_{\mathrm{n}}$ ) is a bona fide in vivo substrate of RNase III. We have not been able to do this here. What we have shown is that lack of RNase III leads to the accumulation of a novel form of RNAI (a possible substrate?) and that certain RNAI decay products are not observed when RNase III is absent (possible products?).

An in vitro demonstration that RNase III could cut RNAI to produce the products observed in vivo would support the hypothesis that RNAI is an RNase III substrate in the cell. Our in vitro results show very specific cutting by RNase III, but only at what are normally regarded as 'low-specificity' sites (Li et al., 1993; Dunn, 1976), that is, sites cut only when ionic strength is low. However, since RNase III cleavage of RNAI is not a preferred reaction in vivo, and indeed appears to occur principally on adenylated substrates or in the absence of RNase E or PAP I, inefficient cutting could ensure that RNase III processing does not take precedence over that carried out by RNase E. It is interesting to note that RNase III, which cuts p10Sa RNA in vivo, only cuts this substrate in vitro in low salt in a reaction requiring $\mathrm{Mn}^{2+}$ but inhibited by $\mathrm{Mg}^{2+}$ (Srivastava et al., 1992). This shows that special conditions can be required for RNase III cutting of particular substrates and that the existence of a cellular factor that promotes RNase III cutting of adenylated RNAI cannot be excluded. Taken together our results are consistent with the possibility, but do not prove, that RNAI is a substrate for RNase III.

A loose consensus sequence has been suggested for RNase III recognition (Krinke \& Wulff, 1990) but it remains difficult to identify a potential substrate on the basis of sequence alone. RNase III can cut the stems of folded single-stranded RNA molecules; although RNAI has three stem-loops these are rather shorter than the stems which have principally been described as RNase III substrates. However, Matsunaga et al. (1996) have reported that a much reduced stem in $r n c \mathrm{O}$, shorter than the RNAI stems, remains a substrate, although a less efficient one, for RNase III cutting.

\section{A suggested pathway for RNAI decay which includes RNase III}

Based on the observations reported here and elsewhere we propose that these are the major reactions leading to RNAI decay (Fig. 7).

(1) The initial processing of $\mathrm{RNAI}_{108}$ is carried out either by RNase E or PAP I.

(2) $\mathrm{RNAI}_{108} \mathrm{~A}_{\mathrm{n}}$ is not converted to $\mathrm{RNAI}_{103} \mathrm{~A}_{\mathrm{n}}$ by RNase $\mathrm{E}$, but is instead broken down by reactions dependent on RNase III. Fig. 1 shows a possible structure for $\mathrm{RNAI}_{108} \mathrm{~A}_{\mathrm{n}}$, based on the assumption that some of the $3^{\prime}$ As can pair with $5^{\prime}$ Us. (It is interesting to note that the longest forms of RNAI we observe, $\sim 117 \mathrm{nt}$, are equivalent to $1 \mathrm{~A}$ per unpaired $5^{\prime}$ nucleotide.) $\mathrm{RNAI}_{108} \mathrm{~A}_{\mathrm{n}}$ is not readily removed by exonucleases; in the absence of RNase III it remains stable. This is particularly surprising in view of the fact that PNPase is increased 10-fold in $r n c$ strains.

(3) $\mathrm{RNAI}_{103}$ is converted to $\mathrm{RNAI}_{103} \mathrm{~A}_{\mathrm{n}}$ by PAP I. That this reaction can be carried out independently of RNase E cutting was shown by inducing PAP I in a $\Delta p c n B$ strain. Accumulated $\mathrm{RNAI}_{103}$ then disappeared rapidly (data not shown).

(4) PNPase promotes $\mathrm{RNAI}_{103} \mathrm{~A}_{\mathrm{n}}$ decay. In the absence of PNPase, $\mathrm{RNAI}_{103} \mathrm{~A}_{\mathrm{n}}$ accumulates (Xu \& Cohen, 1995; and Fig. 1). That PNPase can work independently of RNase $\mathrm{E}$ is shown by the fact that pre-existing $\mathrm{RNAI}_{103}$ is rapidly degraded after PAP I induction.

Thus we suggest that RNAI decay can proceed by one of two principal routes, both of which require that it be adenylated by PAP I. The primary pathway of decay starts with RNase E cleavage, and is followed by PAP-Imediated adenylation and PNPase-mediated exonucleo- 
lytic decay. The secondary route begins with adenylation of $\mathrm{RNAI}_{108}$. Since RNase E does not appear to cleave adenylated $\mathrm{RNAI}_{108}$, RNase III is required. In a $p c n B$ rne $r n c$ mutant, from which RNase E, RNase III and PAP I are absent, $\mathrm{RNAI}_{108}$ none the less continues to disappear. There thus must be other enzymes which are able to initiate its decay.

\section{Implications for mRNA decay}

Several of the observations we have made here may have implications for the way in which RNAs other than RNAI turn over. Firstly, each step in RNAI decay seems to require a specific enzyme which does not appear to be replaceable by another enzyme with similar activity. Thus we see that although either RNase II or PNPase is required for cell viability (Donovan \& Kushner, 1986), suggesting that they can substitute for one another, they do not appear to be able to do so here. Presumably the strong 3' stem-loop prevents RNase II action, possibly by denying it an anchor (Cannistraro \& Kennell, 1994), while added A residues offer a 'handle' for PNPase attack (Xu \& Cohen, 1995). Secondly, 3' adenylation is not necessarily sufficient to allow PNPase attack: adenylated $\mathrm{RNAI}_{108}$ appears very resistant. This could in part be because the 5'ppp interferes with PNPase activity, as has been reported for pppRNAI ${ }_{103}$ (Xu \& Cohen, 1995) and RNase E unprocessable RNAI derivatives (Bouvet \& Belasco, 1992), but the degree of resistance suggests another cause. One possibility is that, although this would not be a strong interaction, the $5^{\prime}$ A-tract base-pairs with the 3' single-stranded region to sequester both the RNase E cutting site and the singlestranded 3' end (Fig. 1). Although a mRNA, because it is much longer than RNAI, is likely to be susceptible to several alternative decay routes (Haugel-Nielsen et al., 1996; Coburn \& Mackie, 1996), any given subsegment may be as restricted as is RNAI in the way in which it can be degraded.

Several associations of enzymes which may expedite RNA decay have been described. The 'degradosome' is a copurifying group of enzymes, which include RNase E and PNPase, with RNA-degrading activity. It has been suggested that the absence of RNase E or PNPase may strongly reduce the rate at which the other can act on its RNAI substrate (Xu \& Cohen, 1995). We do not find evidence of that here. Although the half-life of RNAI is increased in $p n p$ mutants, the stable material has been processed by RNase $\mathrm{E}$; there is no accumulation of $\mathrm{RNAI}_{108}$, unprocessed by RNase $\mathrm{E}$, in $p n p p c n B$ mutants. Furthermore, digestion of $\mathrm{RNAI}_{103} \mathrm{~A}_{\mathrm{n}}$ by PNPase can be separated in time from RNaseE action (by inducing PcnB production in a $p c n B$ background). Thus although endo- and exonucleases may well be associated in the cell, effective in vivo activity does not require coordinate action.

\section{ACKNOWLEDGEMENTS}

We thank A. Nicholson for the kind gift of purified RNase III, the Medical Research Council of the UK for financial support and D. Donachie for aid with figure preparation.

\section{REFERENCES}

Apirion, D. (1978). Isolation, genetic mapping, and some characterization of a mutation in Escherichia coli that affects the processing of ribonucleic acid. Genetics 90, 659-671.

Babitzke, P., Granger, L., Olszewski, J. \& Kushner, S. R. (1993). Analysis of mRNA decay and rRNA processing in Escherichia coli multiple mutants carrying a deletion in RNase III. J Bacteriol 175, 229-239.

Bardwell, J. C., Régnier, P., Chen, S. M., Nakamura, Y., GrunbergManago, M. \& Court, D. L. (1989). Autoregulation of RNase III operon by mRNA processing. EMBO J 8, 3401-3407.

Bolivar, F. (1978). Construction and characterization of new cloning vehicles. III. Derivatives of plasmid pBR322 carrying unique EcoRI sites for selection of EcoRI-generated recombinant DNA molecules. Gene 4, 121-136.

Bouvet, P. \& Belasco, J. G. (1992). Control of RNase E-mediated RNA degradation by $5^{\prime}$ - terminal base pairing in E. coli. Nature 360, 488-491.

Brenner, M. \& Tomizawa, J. (1991). Quantitation of ColE1encoded replication elements. Proc Natl Acad Sci USA 88, 405-409.

Cannistraro, V. J. \& Kennell, D. (1994). The processive reaction mechanism of ribonuclease II. J Mol Biol 243, 930-943.

Carpousis, A. J., Houve, G. V., Ehretsmann, C. \& Krisch, H. M. (1994). Copurification of E. coli RNAse E and PNPase: evidence for a specific association between two enzymes important in RNA processing and degradation. Cell 76, 889-900.

Cesareni, G., Helmer-Citterich, M. \& Castagnoli, L. (1991). Control of ColE1 plasmid replication by antisense RNA. Trends Genet 7 , 230-235.

Church, G. M. \& Gilbert, G. (1984). Genomic sequencing. Proc Natl Acad Sci USA 81, 1991-1995.

Coburn, G. A. \& Mackie, G. A. (1996). Differential sensitivities of portions of the mRNA for ribosomal protein S20 to 3'exonucleases dependent on oligoadenylation and RNA secondary structure. J Biol Chem 271, 15776-15781.

Cohen, S. N. (1995). Surprises at the $3^{\prime}$ end of prokaryotic RNA. Cell 80, 829-832.

Donovan, W. P. \& Kushner, S. R. (1986). Polynucleotide phosphorylase and ribonuclease II are required for cell viability and mRNA turnover in Escherichia coli K-12. Proc Natl Acad Sci USA 83, 120-124.

Dunn, J. J. (1976). RNase III cleavage of single-stranded RNA. J Biol Chem 251, 3807-3814.

Dunn, J. J. \& Studier, F. W. (1973). T7 early RNAs and Escherichia coli ribosomal RNAs are cut from large precursor RNAs in vivo by ribonuclease III. Proc Natl Acad Sci USA 70, 3296-3300.

Elble, R. C., Schneider, J. C., Tamm, J., Muesing, M. A. \& Polisky, B. (1983). Analysis of recessive high copy number mutants of ColE1. UCLA Symp 10, 303-315.

Furste, J. P., Pansegrau, W., Frank, R., Blocker, H., Scholz, P., Bagdasarian, M. \& Lanka, E. (1986). Molecular cloning of the RP4 primase region in a multi-host-range tacP expression vector. Gene 48, 119-131.

Ghora, B. K. \& Apirion, D. (1978). Structural analysis and in vitro processing to $\mathrm{p} 5$ (5S) rRNA of a 9S RNA molecule isolated from an rne mutant of E. coli. Cell 15, 1055-1066.

Guzman, L. M., Belin, D., Carson, M. J. \& Beckwith, J. (1995). Tight regulation, modulation and high-level expression by vectors containing the arabinose $\mathrm{P}_{\mathrm{BAD}}$ promoter. J Bacteriol 95, 4121-4130. 
Hajnsdorf, E., Braun, F., Haugel-Nielsen, J. \& Régnier, P. (1995). Polyadenylation destabilizes the $r p s \mathrm{O}$ mRNA of Escherichia coli. Proc Natl Acad Sci USA 92, 3973-3977.

Haugel-Nielsen, J., Hajnsdorf, E. \& Régnier, P. (1996). The $r p s O$ mRNA of Escherichia coli is polyadenylated at multiple sites resulting from endonucleolytic processing and exonucleolytic degradation. EMBO J 15, 3144-3152.

He, L., Söderbom, F., Wagner, E. G. H., Binnie, U., Binns, N. \& Masters, M. (1993). PcnB is required for the rapid degradation of RNA I, the antisense RNA that controls the copy number of ColE1-related plasmids. Mol Microbiol 9, 1131-1142.

Kaberdin, V. R., Chao, Y. H. \& Lin-Chao, S. (1996). RNase E cleaves at multiple sites in bubble regions of RNA I stem loops yielding products that dissociate differentially from the enzyme. $J$ Biol Chem 271, 13103-13109.

Krinke, L. \& Wulff, D. L. (1990). The cleavage specificity of RNase III. Nucleic Acids Res 18, 4809-4815.

Kushner, S. R. (1996). mRNA decay. In Escherichia coli and Salmonella: Cellular and Molecular Biology, pp. 849-860. Edited by F. C. Neidhardt and others. Washington, DC: American Society for Microbiology.

Kuwano, M., Ono, M., Endo, H., Hori, K., Nakamura, K., Hirota, Y. \& Ohnishi, Y. (1977). Gene affecting longevity of mRNA: a mutant of E. coli with altered mRNA stability. Mol Gen Genet 154, 279-285.

Li, H.-L., Chelladurai, B. S., Zhang, K. \& Nicholson, A. W. (1993). Ribonuclease III cleavage of bacteriophage T7 processing signal. Divalent cation specificity, and specific anion effects. Nucleic Acids Res 21, 1919-1925.

Lin-Chao, S. \& Bremer, H. (1986). Effect of bacterial growth rate on replication control of plasmid pBR322 in Escherichia coli. Mol Gen Genet 203, 143-149.

Lin-Chao, S. \& Cohen, S. N. (1991). The rate of processing and degradation of antisense RNA I regulates the replication of ColE1-type plasmids in vivo. Cell 65, 1233-1242.

Lin-Chao, S., Wong, T. T., McDowall, K. J. \& Cohen, S. N. (1994). Effects of nucleotide sequence on the specificity of $r n e$-dependent and RNase E-mediated cleavages of RNA I encoded by the pBR322 plasmid. J Biol Chem 269, 10797-10803.

Liu, J. D. \& Parkinson, J. S. (1989). Genetics and sequence analysis of the $p c n B$ locus, an Escherichia coli gene involved in plasmid copy number control. J Bacteriol 171, 1254-1261.

Lopilato, J., Bortner, S. \& Beckwith, J. (1986). Mutations in a new chromosomal gene of Escherichia coli K-12, pcnB, reduce plasmid copy number of pBR322 and its derivatives. Mol Gen Genet 205, 285-290.

March, J. B., Colloms, M. D., Hart-Davis, D., Oliver, I. R. \& Masters, M. (1989). Cloning and characterization of an Escherichia coli gene, $p c n B$, affecting plasmid copy number. Mol Microbiol 3, 903-910.

Masters, M., Colloms, M. D., Oliver, I. R., He, L., Macnaughton, E. J. \& Charters, Y. (1993). The pcnB gene of Escherichia coli, which is required for ColE1 copy number maintenance, is dispensable. J Bacteriol 175, 4405-4413.

Matsunaga, J., Simons, E. L. \& Simons, R. W. (1996). RNase III autoregulation: structure of $\mathrm{rncO}$, the posttranscriptional 'operator'. RNA 2, 1228-1240.
Miczak, A., Kaberdin, V. R., Wei, C. L. \& Lin-Chao, S. (1996). Proteins associated with $\mathrm{RNase} \mathrm{E}$ in a multicomponent ribonucleolytic complex. Proc Natl Acad Sci USA 93, 3865-3869.

Nierlich, D. P. \& Murakawa, G. J. (1996). The decay of bacterial messenger RNA. Prog Nucleic Acid Res Mol Biol 52, 153-216.

O’Hara, E. B., Cheakanova, J. A., Ingle, C. A., Kushner, Z. R., Peters, E. \& Kushner, S. R. (1995). Polyadenylation helps regulate mRNA decay in Escherichia coli. Proc Natl Acad Sci USA 92, 1807-1811.

Ono, M. \& Kuwano, M. (1979). A conditional lethal mutation in an Escherichia coli strain with a longer chemical life-time of mRNA. J Mol Biol 129, 343-357.

Piedade, J., Zilhão, R. \& Arriano, C. M. (1995). Construction and characterization of an absolute deletion mutant of Escherichia coli ribonuclease II. FEMS Microbiol Lett 27, 187-194.

Portier, C., Dondon, L., Grunberg-Manago, M. \& Regnier, P. (1987). The 1st step in the functional inactivation of the Escherichia coli polynucleotide phosphorylase messenger is ribonuclease-III processing at the $5^{\prime}$ end. EMBO J 6, 2165-2170.

Py, B., Causton, H., Mudd, E. A. \& Higgins, C. F. (1994). A protein complex mediating mRNA degradation in Escherichia coli. Mol Microbiol 14, 717-729.

Reiner, A. M. (1969). Isolation and mapping of polynucleotide phosphorylase mutants of Escherichia coli. J Bacteriol 97, 1437-1443.

Sarkar, N. (1996). Polyadenylation of mRNA in bacteria. Microbiology 142, 3124-3133.

Srivastava, R. A., Srivastava, N. \& Apirion, D. (1992). Characterization of the RNA processing enzyme RNase III from wild type and overexpressing Escherichia coli cells in processing natural RNA substrates. Int J Biochem 34, 737-749.

Tomcsányi, T. \& Apirion, D. (1985). Processing enzyme ribonuclease E specifically cleaves RNA I, an inhibitor of primer formation in plasmid DNA synthesis. J Mol Biol 185, 713-720.

Tomizawa, J. \& Itoh, T. (1981). Plasmid ColE1 incompatibility determined by interaction of RNA I with primer transcript. Proc Natl Acad Sci USA 78, 6096-6100.

Triezenberg, S. J. (1992). Primer extension. Section 4.8.1. In Current Protocols in Molecular Biology. Edited by F. M. Ausubel, R. Brent, R. E. Kingston, D. D. Moore, J. G. Seidman, J. A. Smith \& K. Struhl. New York: Wiley.

Wagner, E. G. H. \& Simons, R. W. (1994). Antisense RNA control in bacteria, phage and plasmids. Annu Rev Microbiol 48, 713-742.

Xu, F. \& Cohen, S. N. (1995). RNA degradation in Escherichia coli regulated by $3^{\prime}$ adenylation and 5' phosphorylation. Nature 374, 180-183.

Xu, F., Lin-Chao, S. \& Cohen, S. N. (1993). The Escherichia coli $p c n B$ gene promotes adenylation of antisense RNA I of ColE1type plasmids in vivo and degradation of RNA I decay intermediates. Proc Natl Acad Sci USA 90, 6756-6760.

Yancey, S. D. \& Kushner, S. R. (1990). Isolation and characterization of a new temperature-sensitive polynucleotide phosphorylase mutation in Escherichia coli K-12. Biochimie 72, 835-843.

Received 13 April 1999; revised 15 July 1999; accepted 21 July 1999. 